\title{
Analisis Kemampuan Siswa SMA Kabupaten Sumba Barat Daya Menyelesaikan Soal Higher Order Thinking Skills (HOTS) dalam Pembelajaran Matematika
}

\author{
Edi Wahyudi/Samuel Rex Making Mulyadi \\ Pendidikan Matematika, Sekolah Tinggi Keguruan dan Ilmu Pendidikan Weetebula \\ wahyudie9222@gmail.com
}

\begin{abstract}
This research aims to describe the competence of Senior High School students at South West Sumba in doing the high order thinking skills test on math lesson. This research is a survey research with 274 students of eleven SMA/MA in South West Sumba as the samples of research. The instrument used in this research was high order thinking skills test which are divided into 1 analysis test, 1 evaluation test and 1 creating test. The instrument has been tested in terms of construct validation and reliability by doing the instrument testing. The percentage of students who answer correctly on higher order thinking skills at analysis aspect with the ability of problem solving which are understanding the problems, making plans and finding solutions are $85.8 \%, 68.2 \%$ and $65.7 \%$. The percentage of students who answer correctly on evaluation aspect with the ability of problem solving which include understanding the problem, making plans and finding solutions are 61.3\%, $13.0 \%$ and $24.5 \%$. While the percentage of students who answer correctly on creating aspect with the ability of problem solving that include understanding the problem, making plans and finding solutions are $15.3 \%, 13.5 \%$ and $12 \%$. The average score gained by the students on analysis, evaluation and creating aspect which are converted on score $0-100$ are 54, 37 and 34.
\end{abstract}

Keywords: analys, ability, higher order thinking skills.

Abstrak. Penelitian ini bertujuan untuk mendeskripsikan kemampuan siswa SMA di Kabupaten Sumba Barat Daya dalam menyelesaikan soal Higher Order Thinking Skills dalam pembelajaran matematika. Penelitian ini merupakan penelitian survei dengan sample penelitian sebanyak 274 siswa SMA/MA di Kabupaten Sumba Barat daya yang terdiri dari 11 sekolah. Instrumen yang digunakan dalam penelitian ini berupa tes kemampuan tingkat tinggi siswa yang terdiri dari 1 soal menganalisis, 1 soal mengevaluasi dan 1 soal mencipta. Instrumen yang digunakan telah dilakukan uji validitas konstruk dan reliabilitas dengan melakukan uji coba instrumen. Persentase siswa menjawab benar soal Higher Order Thinking Skills pada aspek menganalisis dengan kemampuan pemecahan masalah yaitu memahami masalah, membuat rencana dan melakukan penyelesaian sebanyak $85.8 \%, 68.2 \%$ dan $65.7 \%$. Persentase siswa menjawab benar pada aspek mengevaluasi dengan kemampuan pemecahan masalah yaitu memahami masalah, membuat rencana dan melakukan penyelesaian sebanyak $61.3 \%, 13.0 \%$ dan $24.5 \%$. Sedangkan persentase siswa menjawab benar pada aspek mencipta dengan kemampuan pemecahan masalah yaitu memahami masalah, membuat rencana dan melakukan penyelesaian sebanyak $15.3 \%$, $13.5 \%$ dan $12 \%$. Rata-rata nilai yang diperoleh siswa dari aspek menganalisis, mengevaluasi dan mencipta dengan konversi nilai 0-100 yaitu 54, 37 dan 34.

Kata Kunci: analisis, kemampuan, HOTS.

\section{PENDAHULUAN}

Pendidikan merupakan sarana bagi setiap orang untuk mengembangkan potensi diri, pengetahuan, sumber daya manusia dan mengembangkan potensi diri sebagaimana yang tertuang di dalam Sistem Pendidikan Nasional Tahun 2003 Nomor 20. Salah satu pembelajaran yang penting dalam dunia pendidikan di Indonesia adalah pelajaran matematika, dimana matematika memegang peranan penting dan menjadi dasar dari ilmu pengetahuan. Silabus Mata Pelajaran Matematika SMA/SMK/MA secara umum menyebutkan tujuan dari pembelajaran matematika agar peserta didik 
memiliki kecakapan atau kemahiran matematika terutama dalam pengembangan penalaran, komunikasi, pemecahan masalah (problem solving) yang dihadapi dalam kehidupan seharihari [1]. Badan Standar Pendidikan Nasional secara khusus menyebutkan pembelajaran matematika diharapkan dapat mengembangkan kemampuan berpikir logis, analisis, sistematis, kritis dan kreatif, serta kemampuan bekerja sama [2]. Untuk menggapai tujuan pembelajaran yang telah ditargetkan pemerintah yaitu dengan membekali peserta didik keterampilan, salah satu keterampilan yang dimiliki peserta didik adalah kemampuan berpikir tingkat tinggi atau Higher Order Thinking Skills (HOTS). Keterampilan tingkat tinggi siswa disasarkan pada kemampuan tingkat dasar siswa yang meliputi mengingat, memahami, menerapkan, menganalisis dan metagonitif pengetahuan sebelumnya terkait konten pelajaran. Keterampilan berpikir tingkat tinggi merupakan bagian dari berpikir kritis, logis, reflektif, metakognitif dan kreatif [3]. Hal ini tentu sejalan dengan tujuan pembelajaran matematika dan keterampilan berpikir tinggi dapat memberikan kejelasan, keputusan, kinerja, dan produk yang valid dalam konteks pengetahuan dan keterampilan intelektual peserta didik.

Orientasi pendidikan sekarang tidak hanya sebatas kemampuan dasar dan proses transfer pengetahuan dari pendidik ke peserta didik. Dengan semakin cepatnya perubahan dalam dunia pendidikan, maka HOTS sangat diperlukan peserta didik. Newman, King, dan Carmichael [4] HOTS membuat peserta didik memahami konsep lebih baik, dengan HOTS dapat membedakan ide secara jelas, berargumen dengan baik, mampu menyelesaikan permasalahan, dapat mengkonstruksi pemahaman, membuat hipotesis dan memahami permasalahan kompleks menjadi lebih jelas. Permasalahan dalam kehidupan sesungguhnya adalah bersifat kompleks, baru, dan memerlukan keterampilan berpikir yang lebih dari kemampuan dasar yang telah dipelajari.

Rendahnya hasil TIMSS peserta didik tentunya disebabkan berbagai faktor, diantaranya karena rendahnya kemampuan HOTS peserta didik Indonesia. Winataputra [5] rendahnya hasil TIMSS ini menunjukkan rendahnya prestasi peserta didik Indonesia dalam menyelesaikan soal Higher Order Thinking Skills [HOTS]

Hasil Ujian Nasional matematika Tingkat SMA Negeri dan SMA Swasta tahun 2019 yang dihimpun dari website resmi Puspendik [6] di Kabupaten Sumba Barat Daya yaitu 32,46, Pulau Sumba yaitu 32,1, dan Provinsi Nusa Tengara Timur yaitu 32,91 ; Nilai yang diperoleh masih tergolong rendah dan nilai ini mengindikasikan nilai HOTS peserta didik juga rendah.

\section{Higher Order Thinking Skills}

Benjamin S. Bloom dan rekan-rekannya membentuk urutan tingkatan tujuan pendidikan yang sering disebut sebagai Bloom's Taxonomy atau Taksonomi Bloom. Taksonomi Bloom berkaitan dengan aspek kognitif (pengetahuan, pemahaman, pengembangan sikap intelektual, dan keterampilan), mengklasifikasi tujuan pendidikan pada tingkat berpikir yang berbeda mulai dari tingkat dasar sampai pada tingkat pengetahuan yang lebih tinggi, tingkat dasar meliputi mengingat, memahami, menerapkan dan tingkatan yang lebih tinggi yaitu menganalisis, mensintesis dan mengevaluasi[7]. Kendal dan Marzano [8] menyimpulkan terdapat tiga tingkatan dalam taksonomi yang terbagi menjadi sistem kognitif, sistem metakognitif, dan sistem diri. Sistem kognitif memuat proses memperoleh informasi, pemahaman, analisis dan penggunaan pengetahuan. Sistem metakognitif memuat menentukan tujuan, proses peninjauan, kejelasan peninjauan dan ketepatan peninjauan. Selanjutnya sistem diri memuat memeriksa pentingnya, memeriksa efikasi, memeriksa respon emosional, dan memeriksa motivasi. Krulik \& Rudnick membagi tingkat berpikir menjadi empat kategori, yaitu creative, critical, basic, dan recall dan mengelompokkan kategori tingkat tinggi hanya pada creative dan critical [9] Kemampuan berpikir tingkat tinggi (HOTS) dikembangkan dari taksonomi Blooms, sehingga terbentuk dimensi berpikir kritis, berpikir kreatif, pemecahan masalah, pengambilan keputusan dan metakognitif, serta beberapa hal yang penting atau dominan[10]. Haladyna menyatakan bahwa HOTS mencakup memahami fakta, konsep, prinsip dan prosedur. Pada taksonomi Bloom, aspek pengetahuan, pemahaman dan aplikasi dikategorikan dalam kategori Lower Order 
Thinking Skills (LOTS), sedangkan tiga tingkat lainnya yaitu menganalisis, mensintesis, dan mengevaluasi termasuk dalam HOTS [11]. Implementasi HOTS pada konteks penilaian, bukan hanya kemampuan mengingat kembali informasi (recall), tetapi lebih mengukur kemampuan lainnya yaitu 1) transfer dari satu konsep ke konsep yang lainnya; 2) memproses dan menerapkan informasi; 3) mencari keterkaitan dari berbagai informasi yang berbeda; 4) menggunakan informasi yang ada untuk menyelesaikan masalah; dan 5) menelaah ide dan informasi secara kritis. Meskipun demikian, soal-soal yang berbasis HOTS tidak berarti merupakan soal yang lebih sulit daripada soal recall [12]

Anderson \& Krathwohl dalam taksonomi melibatkan dua dimensi dasar, dimana yang pertama disebut sebagai dimensi pengetahuan/kognitif yang melibatkan empat jenis pengetahuan; pengetahuan faktual, pengetahuan konseptual, pengetahuan prosedural, dan pengetahuan metakognitif [13]. Lebih lanjut Anderson \& Krathwohl [13] membagi aspek berpikir tingkat tinggi HOTS terdiri dari tiga kemampuan yaitu analyzing (menganalisis) melibatkan proses pemecahan materi/bahan ke dalam bagian-bagian penyusunnya dan menentukan bagaimana kegiatan tersebut berhubungan dengan satu sama lain dan struktur secara keseluruhan. Dimensi proses pengetahuan kelima evaluating (mengevaluasi) melibatkan proses membuat penilaian berdasarkan kriteria dan standar. Pada proses evaluasi, siswa membuat keputusan tentang kesesuaian suatu prosedur untuk menyelesaikan masalah tertentu. Selanjutnya dimensi proses yang terakhir creating (mencipta) melibatkan proses penempatan unsur-unsur secara bersama-sama untuk membuat bentuk yang koheren atau fungsional. Proses mencipta (kreatif) dapat dibagi menjadi tiga tahap: penggambaran masalah, yang di dalamnya siswa berusaha memahami permasalahan dan mencari solusinya; perencanaan solusi, yang di dalamnya siswa mengkaji kemungkinan-kemungkinan dan membuat rencana yang dapat dilakukan; dan menentukan solusi, yang di dalamnya siswa berhasil melaksanakan rencananya dengan baik.

\section{Pemecahan Masalah}

Pemecahan masalah merupakan suatu usaha untuk mencari jalan keluar dari suatu kesulitan guna mencapai suatu tujuan yang tidak cepat dicapai [15]. Sumarmo mengartikan pemecahan masalah sebagai kegiatan menyelesaikan soal cerita, menyelesaikan soal yang tidak rutin, mengaplikasikan matematika dalam kehidupan sehari-hari atau keadaan lain dan membuktikan atau menciptakan[16]. Lebih lanjut Gagne berpendapat bahwa dalam menyelesaikan pemecahan masalah diperlukan aturan kompleks atau aturan tingkat tinggi dan aturan tingkat tinggi dapat dicapai setelah menguasai aturan dan konsep terdefinisi [17]. Dewey memberikan lima langkah utama dalam memecahkan masalah yaitu; (1) mengenali atau menyajikan masalah, (2) mendefinisikan masalah, mengembangkan beberapa hipotesis, (4) menguji beberapa hipotesis, dan (5) memilih hipotesis yang terbaik [18]. Menurut Polya [15] solusi soal pemecahan masalah memuat empat fase penyelesaian, yaitu: (1) memahami masalah, (2) merencanakan penyelesaian, (3) menyelesaikan masalah sesuai rencana, dan (4) melakukan pengecekan kembali terhadap semua langkah yang telah dikerjakan. Analisis pemecahan masalah dalam penelitian ini hanya menggunakan 3 langkah pada Model Polya yaitu: (1) Memahami Masalah; pada tahap ini, kegiatan pemecahan masalah diarahkan untuk membantu peserta didik menetapkan apa yang diketahui pada permasalahan dan apa yang ditanyakan; (2) Membuat Rencana untuk Menyelesaikan Masalah; siswa diarahkan untuk mengidentifikasi strategi-strategi pemecahan yang sesuai untuk memecahkan masalah. Dalam mengidentifikasi pemecahan masalah, hal yang harus diperhatikan adalah strategi tersebut harus berkaitan dengan masalah yang akan dipecahkan; dan (3) Melaksanakan Penyelesaian Soal; peserta didik diharapkan menyelesaikan soal sesuai dengan apa yang telah direncanakan. Tahap ini peserta didik diminta untuk memahami subtansi dan keterampilan peserta didik dalam melaksanakan langkah kedua.

\section{METODE}

Penelitian ini merupakan penelitian kuantitatif deskriptif dengan jenis penelitian survei. 
Penelitian ini akan dilaksanakan di SMA Negeri dan SMA Swasta se-Kabupaten Sumba Barat Daya. Populasi dalam penelitian ini adalah siswa SMA, sedangkan untuk pengambilan sampel dilakukan dengan memperhatikan strata-strata dalam populasi. Pengambilan sampel dilakukan dengan teknik pengambilan sampel acak proporsional berstrata (stratified proportional random sampling). Teknik sampling proporsional digunakan untuk menentukan sampel secara proporsional untuk setiap strata.

Teknik pengumpulan data dalam penelitian ini yaitu dengan menggunakan instrumen tes berupa soal HOTS matematika, tes digunakan untuk mengumpulkan data atau informasi mengenai proses pengerjaan yang dilakukan peserta didik dalam menyelesaikan soal matematika berupa soal HOTS dengan menggunakan tiga langkah penyelesaian Polya yang terdiri memahami masalah, membuat rencana, dan melaksanakan penyelesaian soal. Instrumen soal terdiri dari 3 soal esai dengan masing-masing 1 soal menganalisis, 1 soal mengevaluasi dan 1 soal mencipta.

\section{HASIL DAN PEMBAHASAN}

Kemampuan Higher Order Thinking Skills siswa SMA/MA di Kabupaten Sumba Barat Daya secara keseluruhan dapat Tabel 1. Jumlah siswa dalam mengerjakan soal benar untuk menganalisis dilihat dari proses penyelesaian Polya meliputi kemampuan memahami masalah (MM) sebanyak 235 siswa, membuat rencana (MR) sebanyak 163 siswa dan Melaksanakan Penyelesaian (MP) sebanyak 42 siswa. Jumlah siswa mengerjakan soal benar pada aspek mengevaluasi dengan kemampuan memahami masalah sebanyak 180 siswa, membuat rencana sebanyak 85 siswa, dan melaksanakan penyelesaian sebanyak 37 siswa. Sedangkan untuk jawaban siswa menjawab benar aspek mencipta dengan kemampuan memahami masalah sebanyak 180 siswa, membuat rencana sebanyak 67 siswa dan melaksanakan penyelesaian sebanyak 33 siswa.

Tabel 1. Jumlah siswa menjawab benar dan salah soal kemampuan tingkat tinggi

\begin{tabular}{|c|c|c|}
\hline M & & JB \\
\hline Mieng & $\mathrm{MM}$ & 235 \\
\hline
\end{tabular}

\begin{tabular}{llcc}
\hline & MR & 163 & 111 \\
\cline { 2 - 4 } & MP & 42 & 232 \\
\hline \multirow{3}{*}{ Mengevaluasi } & MM & 180 & 94 \\
\cline { 2 - 4 } & MR & 85 & 189 \\
\cline { 2 - 4 } & MP & 37 & 237 \\
\hline \multirow{3}{*}{ Mencipta } & MM & 180 & 94 \\
\cline { 2 - 4 } & MR & 67 & 207 \\
\cline { 2 - 4 } & MP & 33 & 241 \\
\hline JB= Jawaban Benar & \multicolumn{2}{l}{ JS= Jawaban Salah } \\
MM= Memahami Masalah & & \\
MR= Membuat Rencana & & \\
MP= Membuat Penyelesaian &
\end{tabular}

Data hasil rata-rata persentase siswa menjawab dengan benar kemampuan menganalisis untuk memahami masalah terlihat pada Gambar 1.

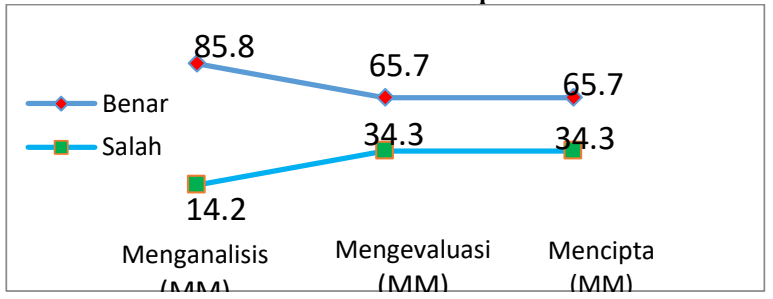

Gambar 1. Grafik persentase siswa menjawab soal menganalisis, mengevaluasi dan mencipta kemampuan memahami masalah

Gambar 1 menunjukkan bahwa kemampuan siswa dalam menyelesaikan soal menganalisis, mengevaluasi dan mencipta pada kemampuan memahami masalah atau menentukan informasi pada soal terlihat bahwa kemampuan siswa untuk soal menganalisis kemampuan memahami masalah persentase benarnya lebih tinggi $(85.8 \%$ siswa menjawab benar) jika dibandingkan dengan kemampuan siswa menyelesaikan soal mengevaluasi dalam memahami masalah $(65.7 \%$ siswa menjawab benar) dan mencipta dalam memahami masalah $(65.7 \%$ siswa menjawab benar).

Siswa yang menjawab benar soal menganalisis kemampuan memahami masalah sebanyak 235 siswa dan menjawab salah 39 siswa. Siswa menjawab benar soal mengevaluasi kemampuan memahami masalah sebanyak 180 siswa dan menjawab salah 94 siswa. Untuk siswa menjawab benar soal mencipta kemampuan memahami masalah sebanyak 180 siswa dan menjawab salah sebanyak 94 siswa. 


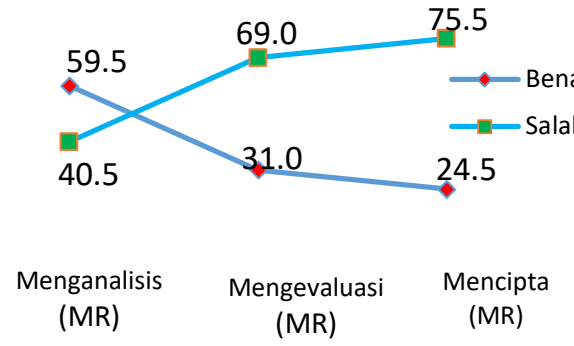

Gambar 2. Grafik persentase siswa menjawab soal menganalisis, mengevaluasi dan mencipta kemampuan membuat rencana

Gambar 2 menunjukkan bahwa kemampuan siswa dalam menyelesaikan soal menganalisis, mengevaluasi dan mencipta pada kemampuan membuat rencana penyelesaian soal terlihat bahwa kemampuan siswa untuk soal menganalisis kemampuan membuat rencana untuk menyelesaikan masalah dengan persentase benarnya lebih tinggi $(59.5 \%$ siswa menjawab benar) jika dibandingkan dengan kemampuan siswa menyelesaikan soal mengevaluasi kemampuan membuat rencana untuk menyelesaikan masalah $(31.0 \%$ siswa menjawab benar) dan mencipta kemampuan membuat rencana penyelesaian masalah $(245 \%$ siswa menjawab benar).

Siswa yang menjawab benar soal menganalisis kemampuan membuat rencana penyelesaian masalah sebanyak 163 siswa dan menjawab salah 111 siswa. Siswa menjawab benar soal mengevaluasi kemampuan membuat rencana penyelesaian masalah sebanyak 85 siswa dan menjawab salah 189 siswa. Untuk siswa menjawab benar soal mencipta kemampuan membuat rencana penyelesaian masalah sebanyak 67 siswa dan menjawab salah sebanyak 241 siswa.

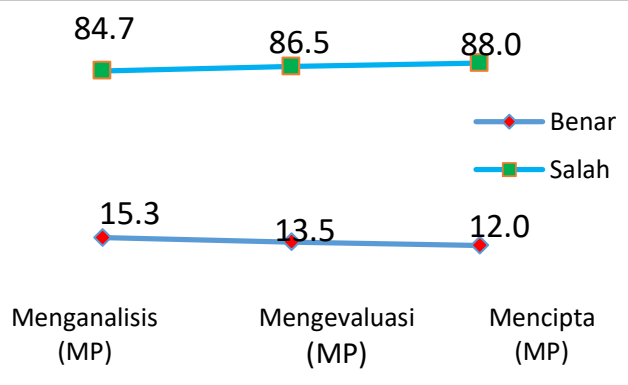

Gambar 3. Grafik persentase siswa menjawab soal menganalisis, mengevaluasi dan mencipta kemampuan membuat penyelesaian akhir

Persentase siswa menjawab jawaban benar proses penyelesaian akhir tergolong rendah karena disebabkan oleh proses penyelesaian akhir ini berhubungan erat dengan pada langkah kedua yaitu membuat rencana. Ketika siswa tidak mampu membuat rencana dengan benar, maka proses penyelesaian akhirnya juga akan salah. Gambar 1 memperlihatkan bahwa rata-rata siswa menjawab benar soal menganalisis, mengevaluasi dan mencipta pengetahuan penyelesaian akhir berturut-turut yaitu $15.3 \%$, $13.5 \%$, dan $12 \%$. Sedangkan persentase siswa yang salah dalam melakukan proses penyelesaian akhir untuk menganalisis, mengevaluasi dan mencipta yaitu $84.7 \%, 86.5 \%$, dan $88 \%$.

Siswa yang menjawab benar soal menganalisis kemampuan membuat penyelesaian akhir sebanyak 42 siswa dan menjawab salah 132 siswa. Siswa menjawab benar soal mengevaluasi kemampuan membuat penyelesaian akhir sebanyak 37 siswa dan menjawab salah 237 siswa. Untuk siswa menjawab benar kemampuan mencipta membuat penyelesaian akhir sebanyak 33 siswa dan menjawab salah sebanyak 241 siswa.

Kemampuan tingkat tinggi siswa SMA di Kabupaten Sumba Barat Daya secara keseluruhan masih tergolong belum mampu mengerjakan soal tes HOST seperti terlihat pada Gambar 4 diagram persentase siswa menjawab benar kemampuan menganalisis, mengevaluasi, dan mencipta.

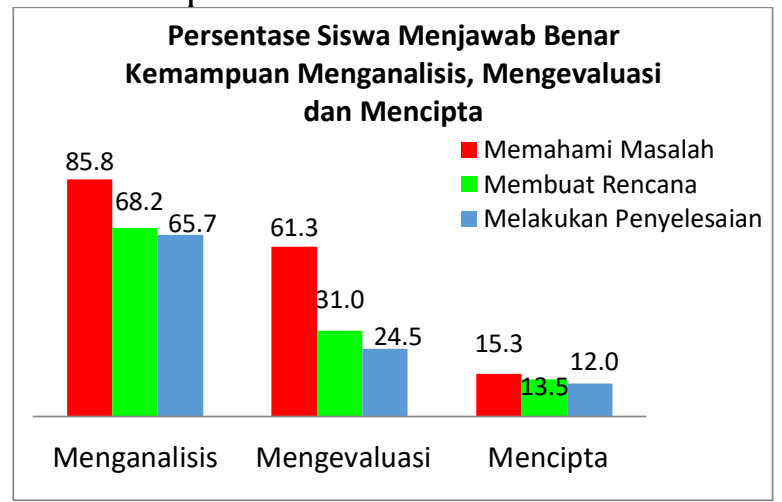

Gambar 4. Diagram persentase siswa menjawab benar soal menganalisis, mengevaluasi dan mencipta 
Rendahnya kemampuan siswa dalam mengerjakan soal HOTS disebabkan karena siswa kurang dalam memahami konsep sehingga siswa kesulitan dalam membuat rencana untuk menyelesaikan soal dan pada akhirnya siswa tidak mampu melakukan penyelesaian akhir. Haolader, (2015, p.114) menyatakan bahwa siswa menunjukkan kemampuan terbaiknya pada saat menyelesaikan tugas pada apek mengingat dan kurang baik dalam mengerjakan aspek yang lebih tinggi. Kemampuan terendah siswa dalam mengerjakan soal tes kemampuan kognitif berada pada aspek mencipta, kemudian mengevaluasi dan menganalisis[19].

Geary \& Fuchs (2010: p.1742) pengembangan kompetensi dalam pemecahan masalah perhitungan prosedural dan masalah kata dari awal sampai akhir bergantung pada kombinasi pengetahuan numerik dan kemampuan umum[20]. Penyebab siswa mengalami kesulitan diantaranya siswa kurang berhati-hati ketika menyelesaikan soal, masih banyak siswa yang kesulitan menyelesaikan operasi aljabar, dan siswa terburu-buru dalam mengerjakan soal sehingga memperoleh jawaban akhir yang salah. dengan melihat jawaban yang diberikan siswa mengerjakan soal matematika, dapat mengetahui seberapa besar kesulitan yang dialami oleh siswa.

\section{KESIMPULAN}

Analisis kemampuan siswa SMA dalam mengerjakan soal HOTS di Kabupaten Sumba Barat Daya soal menganalisis dengan kemampuan pemecahan masalah yaitu memahami masalah, membuat rencana dan melakukan penyelesaian akhir sebanyak $85.8 \%, 68.2 \%$ dan $65.7 \%$. Persentase siswa menjawab benar soal mengevaluasi dengan kemampuan pemecahan masalah yaitu memahami masalah, membuat rencana dan melakukan penyelesaian sebanyak $61.3 \%$, 31\% dan $24.5 \%$. Sedangkan persentase siswa menjawab benar pada aspek mencipta dengan kemampuan pemecahan masalah yaitu memahami masalah, membuat rencana dan melakukan penyelesaian sebanyak $15.3 \%, 13.5 \%$ dan $12 \%$. Rata-rata nilai yang diperoleh siswa dari aspek menganalisis, mengevaluasi dan mencipta dengan konversi nilai 0-100 yaitu 54, 37 dan 34 .

\section{SARAN}

Untuk meningkatkan kemampuan siswa dalam mengerjakan soal HOTS sebaiknya guru membiasakan siswa untuk mengerjakan soal-soal dengan tingkat kesulitan yang lebih tinggi sehingga siswa tidak asing dengan soal HOTS dan terbiasa dalam mengerjakan ketika diberikan soal. Rendahnya hasil siswa dalam mengerjakan soal tes kemampuan tingkat tinggi mungkin juga dipengaruhi oleh pola belajar siswa di sekolah diakibatkan oleh pandemi Covid-19, sehingga siswa tidak secara penuh melakukan proses pembelajaran di sekolah akan tetapi melakukan pembelajaran daring di rumah.

\section{UCAPAN TERIMA KASIH}

Ucapan terima kasih Peneliti ucapkan kepada LLDIKTI yang telah memberikan bantuan dana hibah penelitian sehingga penelitian ini dapat terlaksana dan terselesaikan. Peneliti juga mengucapkan terima kasih kepada Ketua Yayasan Pendidikan Nusa Cencana dan Ketua Sekolah Tinggi Keguruan dan Pendidikan Weetebula yang telah membantu peneliti sehingga dapat melakukan penelitian. Ucapan terima kasih juga peneliti ucapkan kepada Kedua Orang Tua dan Istri yang selalu memberikan dukungan dan motivasi untuk terus semangat dalam melakukan penelitian.

\section{DAFTAR PUSTAKA}

Anderson, L. W., \& Krathwohl, D. R. (2001). A taxonomy for learning, teaching and assessing: A revision of Bloom's Taxonomy of Educational Objectives. New York, NY: Longman.

Bloom, B. S (1956). Taxonomy of educational objectives: The classification of educational goals. New York, NY: McKay.

BNSP. (2006). Standar isi untuk satuan pendidikan dasar dan menengah. Jakarta: Badan Standar Nasional Pendidikan.

Butkowski, J., Corrigan, C., Nemeth, T., \& Spencer, L. (1994). Improving student higher-order thinking skills in mathematics. Theses. Mathematics Education Research, Saint Xavier University-IRI, Fied-Based Master's Program 
Direktorat Pembinaan SMA. (2015). Penyusunan Soal Higher Order Thinking Skills Sekolah Menengah Atas. Jakarta: Direktorat Jenderal Pendidikan Menengah, Kementerian Pendidikan dan Kebudayaan.

Gagne, R.M. (1992). The Condition of Learning and Theory of Instruction. New York: Rinehart and Winston.

Geary, D. C., \& Fuchs, L. S., (2010). Do different types of school mathematics development depend on different constellations of numerical versus general cognitive abilities. American Psychological Association. 46(6), 17311746. DOI: $10.1037 / \mathrm{a} 0020662$.

Haolader, F. A., Ali, R., \& Foysol, K. (2015). The taxonomy for learning, teaching and assessing: Current practices at polytechnics in Bangladesh and its effects in developing students' competences. Research in vocational and traning. 2 (2). 99-118, DOI: 10.13152/IJRVET.2.2.9.

https://puspendik.kemdikbud.go.id/hasil-un/

King, FJ., Goodson, L., \& Rohani, F. (2013) Higher Order Thinking Skills. www.cala.fsu.edu. 06 Agustus 2019.

Krulik, S. \& Rudnick, J. A. (1999). The new sourcebook for teaching reasoning and problem solving in elementary school. Needham Heights: Allyn \& Bacon.

Marzano, R. J., \& Kendall, J. S. (2007). The new taxonomy of education objectives. (2nd ed.). Thousand Oaks, CA: Corwin Press.

Mendikbud. (2016). Silabus Mata Pelajaran Matematika Sekolah Menengah Atas/Madrasah Aliyah/Sekolah Menengah Kejuruan/Madrasah Aliyah Kejuruan.

Newman, F.M., King, M.B, \& Carmichael, D.L. (2007). Authentic instruction and assessment: Common standards for rigor and relevance in teaching academic subjects. Des Moines, IA: Department of Education

Polya, G. (1973). How to Solve It. New Jerse: Princeton University Press
Riadi, A. \& Retnawato. H. (2014). Pengembangan perangkat pembelajaran untuk meningkatkan HOTS pada kompetensi bangun ruang sisi datar. Pythagoras: Jurnal Pendidikan Matematika, 9(2), 126-135.

Rothstein \& Pamela. (1990). Educational Psychology. New York: Mc. Graw Hill, Inc.

Saido, G. M., Siraj, A., Nordin, A. B. B., \& Al Amedy, O. S. (2015). Higher order thinking skills among secondary school students in science learning. The Malaysian Online Journal of Education Science, 3(3), 13-20.

Sumarmo, U, Dedy, E dan Rahmat (1994). Suatu Alternatif Pengajaran untuk Meningkatkan Pemecahan Masalah Matematika pada Guru dan Siswa SMA. Laporan Hasil Penelitian FPMIPA IKIP Bandung.

Yen, T. S. \& Halili, S. H. (2015). Effective teaching of higher-order thinking (HOT) ineducation. The Online Journal of Distance Education and e-Learning, 3(2), 41-47. 